Paul Cliteur* and Afshin Ellian

\title{
The Five Models for State and Religion: Atheism, Theocracy, State Church, Multiculturalism, and Secularism
}

https://doi.org/10.1515/icl-2018-0056

Abstract: This article deals with one of the perennial questions of legal and political philosophy, ie, how the state should relate to religion? It makes a distinction between five models: (i) the atheist state, (ii) the theocratic state, (iii) the model of an official state church, (iv) the multiculturalist state, and (v) the agnostic state (or secular state). The authors reflect on the legitimacy of each of these models. Some states reclaim their right to adopt an official religion as their state religion or as the religious Leitkultur of their country (model iii). Others favor the support of religion as long as this is premised on the equal rights of all religions (model iv). And others think that the state can only support equal citizenship if the state does not support any religion whatsoever (model v).

Keywords: agnosticism, church and state, freedom of religion, multiculturalism, secularism, theocracy

In April 2013, British Prime Minister David Cameron called Great Britain a 'Christian country.' Great Britain ought to become 'evangelical' again. Not everyone agreed and a group of 25 public figures accused the prime minister of sowing discord in the country. ${ }^{1}$ The prime minister should not voice a preference for any religion, his critics argued.

But there was also support for Cameron's position. Bishop Michael Nazir-Ali ( $b$ 1949) said: 'While some acknowledge the debt which Britain owes to the Judeo-

1 John Bingham, 'David Cameron "fueling sectarian division by bringing God into politics”' The Telegraph (20 April 2014).

*Corresponding author: Prof Dr Paul Cliteur, Universiteit Leiden Instituut voor Metajuridica, Institute for the Interdisciplinary Study of the Law, Leiden University, Steenschuur 25, Leiden, 2300 RA, The Netherlands, E-mail: p.b.cliteur@law.leidenuniv.nl

Afshin Ellian, Professor: Universiteit Leiden Instituut voor Metajuridica, Institute for the Interdisciplinary Study of the Law, Steenschuur 25, Leiden, 2300 RA, The Netherlands, E-mail: a.ellian@law.leidenuniv.nl 
Christian tradition, they claim also that the values derived from it are now freestanding and that they can also be derived from other world-views. ${ }^{2}$ Nazir-Ali fears that because this is not possible. There is a danger, he writes, 'that we are living on past capital which is showing increasing signs of being exhausted.'3 This is why, like Cameron, Nazir-Ali believes that we should return to our culture's Christian roots.

The relationship between state and religion has become controversial again. An extra dimension to these discussions is the rise of religious radicalism since the $1980 \mathrm{~s}$ and 1990s. In Judaism, ${ }^{4}$ Christianity, ${ }^{5}$ and Islam, ${ }^{6}$ it is the orthodox and fundamentalist currents that are on the rise. Not moderate religiosity (a 'loose' interpretation of the holy book and a critical attitude with regard to religious authority), but the strictest and most intolerant forms of religious thinking seem to have the wind in their sails, in particular the extremely violent Islamic State. How should the state respond to this?

In this article we want to discuss five models for the relationship between the state and religion. That is because there are five positions the state can take with regard to religion. In other words, every country can choose from these five options to organize its relationship with religion.

They are (i) the atheist state; (ii) the theocratic state; (iii) the state with an official state Church; (iv) the multiculturalist state, and (v) the agnostic state.

\section{What is an 'Atheist' State?}

First, the atheist state. Atheism, in its most elemental form, is a-theism, i. e., the denial of the claims of theism. ${ }^{7}$ Theism is the belief in the existence of a specific God: a personal, transcendent, perfectly benevolent, omnipotent creator of heaven, and Earth. This God is called God. ${ }^{8}$

2 Michael Nazir-Ali, Triple Jeopardy for the West: Aggressive Secularism, Radical Islamism and Multiculturalism (Bloomsbury 2012) 12.

3 ibid 12.

4 Yuval Elizur and Lawrence Malkin, The War Within: Israel's Ultra-Orthodox Threat to Democracy and the Nation (Overlook Duckworth 2013).

5 Damon Linker, The Theocons: Secular America under Siege (Doubleday 2006).

6 Bruce Bawer, While Europe Slept: How Radical Islam Is Destroying the West From Within (Doubleday 2006).

7 PB Cliteur, 'The Varieties of Atheist Experience' (2010) April/May Philosophy Now 6-8; Paul Cliteur, 'The Definition of Atheism' (2009) Vol 11 Journal of Religion and Society 1-23.

8 Bill Cooke, 'Atheism' in Bill Cooke (ed), Dictionary of Atheism, Skepticism, \& Humanism (Prometheus Books 2006) 49-50; Paul Edwards, 'Atheism' in Paul Edwards (ed), The Encyclopedia of Philosophy (Vol I, Macmillan \& The Free Press 1967) 174-189; Ernest Nagel, 'A Defense of Atheism' in Paul Edwards and Arthur Pap (eds), A Modern Introduction to Philosophy (Revised Edition, The Free Press, Collier-Macmillan, 1967 [1957]) 460-473. 
Atheism has a long history, but because in the past atheists were almost always persecuted and punished, it is difficult to ascertain how many atheists actually existed. ${ }^{9}$ Usually, atheism is a label that philosophers hesitate to adopt to describe their own position in religious matters (Spinoza and Hume are examples of thinkers who were labeled atheist and vehemently tried to refute this accusation.) Because the label atheist was considered a stigma and could have serious consequences in some countries, many tried to avoid it, which means that we do not know how many atheists actually exist in the world. So, for the same reason that we do not know how many liberals there are in North Korea or how many critics of Islam there are in Saudi Arabia (most people prefer to keep their heads attached), we also do not know how many atheists there were in 16th and 17th century France. $^{10}$

Not until the 19th century, when religious persecution became less severe, did atheists become more outspoken. Only then did a large-scale atheist 'coming out' occur.

In our time, atheism went through a revival after $9 / 11$ in the form of what is called the new atheism, represented by thinkers such as Christopher Hitchens, Richard Dawkins, ${ }^{11}$ Sam Harris, ${ }^{12}$ Daniel Dennett, ${ }^{13}$ AC Grayling, ${ }^{14}$ Peter Singer, ${ }^{15}$

9 AB Drachmann, Atheism in Pagan Antiquity (Glydendal 1922, reprinted by Kessinger Publishing 2005); JB Bury, A History of the Freedom of Thought (Thornton Butterworth 1932 [1913]); Finngeir Hiorth, Introduction to Atheism (Indian Secular Society 1995).

10 Paul Marshall (ed), Religious Freedom in the World: A Global Report on Freedom and Persecution (Freedom House 2000) 268: 'There are small numbers of Saudis of other religions, especially Christian, but they usually remain hidden since, if discovered, they could be executed as apostates.' On the ways in which 18th century philosophers tried to escape censorship and persecution, see Philipp Blom, Wicked Company: Freethinkers and Friendship in Pre-revolutionary Paris (Phoenix, Weidenfeld \& Nicolson 2012).

11 Richard Dawkins, The God Delusion (Paperback edition, Black Swan, Transworld Publishers 2006).

12 Sam Harris, Letter to a Christian Nation (Alfred A Knopf 2006); Sam Harris, The End of Faith: Religion, Terror, and the Future of Reason (The Free Press 2005).

13 Daniel C Dennett, Breaking the Spell: Religion as a Natural Phenomenon (Allen Lane, Penguin Books 2006).

14 AC Grayling, The God Argument: The Case against Religion and for Humanism (Bloomsbury 2013); AC Grayling, Against all Gods: Six Polemics on Religion and an Essay on Kindness (Oberon Books 2007); AC Grayling, To Set Prometheus Free: Essays on Religion, Reason and Humanity (Oberon Masters 2009).

15 Singer has not written a monography about religion, but his meta-ethical position is wellknown (see, for instance: Marc Hauser and Peter Singer, 'Morality without Religion' December 2005/January 2006 Free Inquiry, 18-19) as are his thoughts on the practical consequences of a secular ethics for bio-ethics. See Peter Singer, Practical Ethics (3rd edn, Cambridge University Press 2011). 
and others. ${ }^{16}$ But it is important to stress one thing, and that is the new atheism like the classical atheism of previous generations is a private atheism. This means that it is a personal conviction of individuals that does not have any ambition to exert political power. On the contrary, Karl Marx's atheism became the basis of a state doctrine. In the Soviet Union, from 1917 onwards, the spreading of atheism became a goal of the state, the 'atheist state.' Marx's remark that religion ought to be abolished was interpreted as a directive for the state. It was considered a job of the state to try to destroy religion as a dangerous societal perversion. The former Soviet Union and Albania were the most famous examples of this. ${ }^{17}$

The claim that atheism as a private doctrine inevitably leads to state atheism is clearly false. ${ }^{18}$ It can be compared to smoking. People can decide that smoking is unhealthy and therefore not smoke, or quit smoking. People can also advise others not to smoke. But it would be unjust to accuse the doctor who gives a person health advice of the ambition to 'force' that person to adopt a healthy lifestyle.

We can compare Hitchens and Dawkins with the doctor from this example. Lenin and Stalin, on the other hand, favored 'involuntary commitment' to a theism rehab clinic. This is an essential difference.

\section{What is a Theocratic State?}

Having discussed the first model of the relationship between state and religion, the atheist state, we now move to the prima facie opposite model (although also comparable: les extrêmes se touchent): the religious fundamentalist or theocratic state, as we see it in, for instance, Saudi Arabia and Iran. ${ }^{19}$ These countries are theocracies, in which theocracy literally means government by God. ${ }^{20}$ But just as a democracy is often governed by representatives of the people, a theocracy is also a government of representatives, in this case of God.

In the case of a theocracy, the representatives are not ordinary politicians but clerics with a powerful political ambition. In a theocracy, religion is unavoidably political.

16 Victor J Stenger, The New Atheism: Taking a Stand for Science and Reason (Prometheus Books 2009); Amarnath Amarasingam (ed), Religion and the New Atheism: A Critical Appraisal (Brill 2010). 17 Sonja Luehrmann, Secularism Soviet Style: Teaching Atheism and Religion in a Volga Republic (Indiana University Press 2011).

18 But often resurfaces. See, for instance Alister McGrath, The Twilight of Atheism. The Rise and Fall of Disbelief in the Modern World (Doubleday 2004).

19 Hans-Peter Raddatz, Iran: Persische Hochkultur und irrationale Macht (Herbig Verlagsbuchhandlung 2006).

20 Amir Taheri, The Persian Night: Iran under the Khomeinist Revolution (Encounter Books 2009). 
It is possible to distinguish two types of religion:

a. Religion as a framework of meaning for individual life.

b. Religion as a shared point of departure for the political community as a whole.

It sounds a bit strange, and that is why this terminology is not common, but it would be clarifying to distinguish between:

a. Religious religion.

b. Political religion.

The first certainly does not need to lead to the second (contrary to what is often argued). ${ }^{21}$ When Spinoza (1632-1677) identifies nature with God ('deus sive natura') in his Ethics (1678, published posthumously), it could be viewed as a religious position. But in his Theologico-Political Treatise (1670), that same Spinoza also develops a scathing criticism of any political religion. ${ }^{22}$

In the upcoming paragraphs, we will provide an extensive analysis of the theocratic state. This model of the relationship between state and religion deserves more time than the first model, because the theocratic state is a kind of ideal for modern-day theoterrorists. Jihadist murderers like Mohammed Bouyeri (of Theo van Gogh, † 2004) and Michael Adebolajo (of Lee Rigby, † 2013), but also their ideologues, such as Osama Bin Laden, Ayman al-Zawahiri, and Ayatollah Khomeini, all seem to be inspired by the idea of a theocratic state, a state ruled by God himself, which is contrasted with a state ruled by mere mortals. That is why it is highly relevant to study this model, just as it was relevant to study the model of the Soviet Union before the fall of the Berlin Wall. ${ }^{23}$ Those who say that the radicals' interpretation of Islam is not Islam in its truest form may be right, but they also totally miss the relevant point. ${ }^{24}$ From a social-science perfective, it does not matter what Islam is but what it is perceived to be. To quote Bishop Berkeley

21 See on this Sohail Wahedi, The Constitutional Dynamics of Religious Manifestations: On abstraction from the religious dimension (Erasmus University Rotterdam 2019).

22 Benedict de Spinoza, Theological-Political Treatise (L 1670, Jonathan Israel ed, Cambridge University Press 2007).

23 As was done by HB Acton, The Illusion of the Epoch: Marxism-Leninism as a Philosophical Creed (Routledge \& Kegan Paul 1962); Joseph M Bochenski, Marxismus-Lenisnismus: Wissenschaft oder Glaube (3rd edn, Günter Olzog Verlag 1975); GA Wetter, Sovietideologie Heute, I, Dialektischer und historischer Materialismus (Fischer Taschenbuch Verlag 1962).

24 That is also why the work of, for instance, Karen Armstrong cannot be viewed as a relevant critique of the ideas developed in this chapter. See Karen Armstrong, A History of God: From Abraham to the Present: the 4000-Year Quest for God (Heinemann 1993); Karen Armstrong, Islam: A Short History (Random House 2002); Karen Armstrong, The Case for God: What Religion Really Means (The Bodley Head 2009). 
(1685-1753), 'To be is to be perceived' (although it is used very differently here than the famous Irish philosopher intended it).

As is extensively discussed in The Freedom of Thought Report 2019: A global report on the rights, legal status and discrimination against humanists, atheists and the non-religious (2019), ${ }^{25}$ and all its predecessors, there is no freedom of religion or belief or freedom of speech in Saudi Arabia. ${ }^{26}$ There is also no separation of Church and state, or anything that might be called political secularism. The royal family, in cooperation with the religious establishment, forces all citizens to abide by the official Wahhabi interpretation of Islam. ${ }^{27}$ Blasphemy and apostasy are punishable by death, although this ultimate punishment is not often carried out. Lesserknown crimes are 'witchcraft' and 'sorcery. ${ }^{28}$ These are punishable by beheading or crucifixion..$^{29}$ Not much is known about most of these cases because, as Amnesty International has said, wrongdoers are convicted by special courts to which the general public does not have access. ${ }^{30}$

\section{Political Islam and Terrorism}

Since the terrorist attacks of 9/11, Saudi Arabia has been closely monitored by the United States and other countries. Domestic terrorist violence (such as the 2003 bombings in the capital, Riyadh) forced the Kingdom to reconsider its approach to religion and civil liberties. In 2004, there was a terrorist attack in Khobar that killed 22 people. ${ }^{31}$ After that, the regime was forced to take the terrorist threat seriously.

The fact that religion is not just an instrument used by the government but also against the Saudi ruling family becomes clear in 2001. In 2001, Sheik Hamoud bin

25 Humanists International, The Freedom of Thought Report 2019: A global report on the rights, legal status and discrimination against humanists, atheists and the non-religious (2019) 98.

26 International Humanist and Ethical Union, Freedom of Thought 2014. A Global Report on the Rights, Legal Status, and Discrimination Against Humanists, Atheists, and the Non-religious (London 2014); International Humanist and Ethical Union, The Freedom of Thought Report 2017: A Global report on the rights, legal status and discrimination against humanists, atheists and the non-religious (IHEU, London 2018).

27 See on this Charles Allen, God's Terrorists: The Wahhabi Cult and the Hidden Roots of Modern Jihad (Little, Brown 2006); Natana J DeLong-Bas, Wahhabi-Islam: From Revival and Reform to Global Jihad (IB Tauris 2007).

28 In 2000, the authorities closed an Ismaili Mosque in the south-western region of Najran because it was said that 'witchcraft' was practiced there. Marshall, Religious Freedom in the World (Rowman \& Littlefield Publishers 2008) 348.

29 IHEU (n 26) 176.

30 IHEU (n 26) 176.

31 Marshall (n 28) 346. 
Oqla al-Shuaibi († 2001) proclaimed a fatwa against the Al-Saud royal family. ${ }^{32}$ The sheik, who was also a supporter of Al Qaeda and who had praised the attacks of 9/ 11, died later that year, but not before he had said that 'whoever backs the infidel against Muslims is considered an infidel. ${ }^{33}$

The sheik had not always been a lonely figure, at odds with the state's official leaders. He had been a respected cleric and scholar who once taught the Saudi chief justice. But when the Saudi royal family sided with the Western powers, they themselves became apostates in the eyes of the exceptionally pious. All Muslims have a duty to wage jihad against those who attack Muslim states. ${ }^{34}$

What this shows is that theocracies are always in a precarious position. In a democracy, any political leader can be replaced by a new leader who gets more votes from the people. In a theocracy, those who claim to rule according to God's dictates can be upstaged by someone who says he knows better what God commands. Every Moses has cause to fear his Phineas. ${ }^{35}$

Both models, the atheist state and the theocratic state (or the philosophies behind these models: political atheism and religious fundamentalism), do not seem very attractive. At least, they are not in harmony with what one could call individual human rights, such as the right to freely choose one's religion or the right to reject a religion that no longer appeals. Contrary to all expectations, theocracy is back in force nowadays. The atheist state has more or less disappeared from the world, while the theocratic state, against all expectations, is enjoying a considerable revival. ${ }^{36}$ 'Religion and faith in God have made a big comeback. In the past decades, principles of theocratic governance have accrued significant support from the public all over the world,' Ran Hirschl writes. ${ }^{37}$ This seems to be true. But the quotation does not say what this means, exactly. It also means that, at the time we write this, thousands of young people from Europe are waging a 'Jihad' to establish a caliphate in Syria and Iraq. They do not fight for democracy, but for theocracy.

32 Laurent Murawiec, Princes of Darkness: The Saudi Assault on the West (George Holoch tr, Rowman \& Littlefield Publishers 2005) 89.

33 'The fatwa against the royal family' The Economist (11 October 2001).

34 ibid.

35 Phineas is a religious fanatic ('zealot') who, on his own initiative, kills two people accused of heresy. God praised Phineas for it. See the story as told in the Bible: Numbers 25 . On the meaning of Phineas, see John T Collins, 'The Zeal of Pinechas: The Bible and the Legitimation of Violence' (Spring 2003) Vol 122 No 1 Journal of Biblical Literature 3-21; Louis H Feldman, 'The Portrayal of Pinechas by Philo, Pseudo-Philo, and Josephus' (Jan-April 2002) Vol 92 No 3/4 The Jewish Quarterly Review, New Series 315-345.

36 See on this Rainer Hermann, Endstation Islamischer Staat? Staatsversagen und Religionskrieg in der arabischen Welt (Deutscher Taschenbuch Verlag 2015).

37 Ran Hirschl, Constitutional Theocracy (Harvard University Press 2010) 1. 
Exactly what constitutes a theocratic state is, of course, open to debate. From a certain perspective, there are no 'true' theocratic states, because God does not involve himself in worldly affairs. ${ }^{38}$ However, we can further specify our definition: a theocratic state is a state in which a large part of the population thinks that God runs the state, or where the ruling classes claim that they run the state on the basis of divine commands. And such countries surely exist in the world. Many states still uphold apostasy laws by which people who wish to change religions have to be punished. Mauritania, Nigeria, Sudan, Egypt, Iraq, Jordan, Kuwait, Saudi Arabia, Yemen, Somalia, Malaysia, Iran, Bahrein, Afghanistan, and Pakistan are examples. ${ }^{39}$ Sooner or later, these countries will have to alter their laws if they want to uphold individual human rights. In all probability though, they have no interest in that to begin with.

Many people who live in Western democracies will consider that last statement to be rather brash. They believe that things are 'much more complex.' But the question is: what is so complicated then?

What makes it complicated for many people is that they believe there is no such thing as universal values. Many people believe that democracy may be right for 'us,' but not for 'them,' for people in other parts of the world, with other mores and attitudes. Many people believe that although freedom of religion is important to 'us,' it is not to 'them,' the people in other countries and cultures. This attitude runs counter to the perspective the Universal Declaration of Human Rights hoped to establish in 1948. Article 18 of the Universal Declaration of Human Rights, passed by the United Nations in 1948, says the following:

Everyone has the right to freedom of thought, conscience and religion; this right includes freedom to change his religion or belief, and freedom, either alone or in community with others and in public or private, to manifest his religion or belief in teaching, practice, worship and observance.

So the freedom to change religions is not some sort of vague moral demand, but a basic human right. However, what worries many commentators when, for instance, Saudi Arabia or Iran is criticized in the Western world, is that they believe that the West does not have the right to judge. They believe this to be 'arrogant,' 'judgmental,' and 'intolerant.'

38 See Bertrand Russell, A History of Western Philosophy (A Touchstone Book, Simon \& Schuster 1972) 247: 'As for the gods, Epicurus firmly believes in their existence, since he cannot otherwise account for the wide-spread existence of the idea of gods. But he is persuaded that they do not trouble themselves with the affairs of our human world.'

39 Angelina Theodorou, 'Which countries still outlaw apostasy and blasphemy' (Pew Research Center, 28 May 2014). See also Paul Cliteur and Tom Herrenberg (eds), The Fall and Rise of Blasphemy Law (with a foreword by Flemming Rose, Leiden University Press 2016). 


\section{What are State Religions?}

The distinction that is usually made between a theocracy (model 2) and a country that has a state religion (model 3) is that a system with a state religion allows other religions to exist alongside it. Proponents of state religions usually claim that their system is a good idea, because members of minority religions are not persecuted. And it is true that in a state-religion system, dissenters are not necessarily persecuted. For instance, in 21st century England, no one is persecuted for not adhering to the Anglican Church (as was the case under Henry VIII). But does that make a state religion an appealing idea? Not quite, because the position of minorities, both religious and non-religious, in a country that has a state religion is not ideal. Because they are discriminated against. After all, the state chooses a single religious position and grants it privileges. In other words, although model 3 of the relationship between Church and state is better than models 1 and 2, it still does not fully satisfy. ${ }^{40}$

Especially in countries with a high level of secularization and religious pluralism, state religions create inequality in the form of religious privileges for a specific part of the population, and this undermines the legitimacy of the state.

It was for this reason that James Madison $(1751-1836)^{41}$ wrote the First Amendment to the American Constitution:

Congress shall make no law respecting an establishment of religion, or prohibiting the free exercise thereof.

As Brian Grim concludes in a country comparison on the freedom of religion, the First Amendment protects minority religions (and the state) against the tyranny of a dominant religion, and the Second Amendment protects religion against the tyranny of the state. ${ }^{42}$

The waning of state religions has been a gradual process in the Western world. In countless matters, the privileges of a single religion (often Christianity) granted by the state have been challenged. A famous American activist in this area was Madalyn Murray O'Hair (1919-1995). She studied law at the South Texas College of

40 See also Paul Cliteur, 'The Crucifix and the Ideal of a Religiously Neutral State' (19 April 2018) Journal of Church and State.

41 See on Madison's views James Madison, Memorial and Remonstrance Against Religious Assessments in James Madison, Writings (first published 1785, The Library of America 1999) 29-39. 42 Brian J Grim, and Roger Finke, The Price of Freedom Denied: Religious Persecution and Conflict in the Twenty-First Century (Cambridge University Press 2011) 6. Incidentally, what Grim overlooks in his analysis is that the free exercise of religion is no longer limited primarily by states but by private groups and individuals: by 'theoterrorism.' 
Law and gained great notoriety in the 1960 s with the trial of Murray versus Curlett, in which she took on the mandatory daily prayer in public schools. The immediate cause of this was the fact that her son William was required to participate in Bible readings in a public school in Baltimore. O'Hair thought this violated the Constitution, which prescribed a separation of Church and state, after all. In the end, on 17 June 1963, the Supreme Court ruled in her favor, and the daily prayer in public schools was ended. It turned her into one of the most controversial people of her day in the United States. ${ }^{43}$ In 1964, the magazine Life proclaimed her to be 'the most hated woman in America,' and she even received many death threats. Nevertheless, O'Hair tirelessly continued her activism. In O'Hair versus Hill (1984) she won another lawsuit. This verdict abolished the discriminatory practice of making civil servants profess a belief in God in order to be considered for a job in the civil service.

Another subject that has created a big stir is that of religiously neutral education. The American lawyer and human rights activist Clarence Darrow (18571938) made a big contribution on this point.

Darrow was born in a family that was once religious but had gradually lost its faith. Although Darrow's parents no longer believed, however, they still did not want to expose their children to the social stigma of non-belief. So they feigned adherence to the faith, and the children were sent to Sunday school.

Darrow later became one of the most iconic jurist in the United States. He specialized in labor law, but he also defended many freethinkers and anarchists. The most important case of his career is of significance to the subject of this chapter: the Scopes Monkey trial of 1925. It started with the introduction of a law in Tennessee in 1920 that banned the teaching of Darwinian evolution in schools. The driving force behind it was the fundamentalist William Jennings Bryan (18601925), a politician and jurist who had tried (and failed) to become president of the United States three times. On the basis of this law, John T Scopes (1900-1970), a twenty-one-year-old teacher in Dayton, Tennessee, was prosecuted. He stood accused of corrupting the minds of the young in biology classes, in which he taught evolution. When Darrow learned that Bryan had offered to act as special prosecutor, he decided to offer his services to Scopes. It was a brave decision; public opinion strongly disfavored Scopes. Initially, Scopes was convicted, although the trial had offered Darrow a chance to submit Bryan to pointed questioning. On appeal though, the verdict was overturned, now favoring Scopes (and thus the teaching of evolution). Largely because of the 'Monkey Trial,' Darrow became a big celebrity in the United States. ${ }^{44}$ At the end of his life, Darrow was so famous that

43 For an overview of her work, see: Bill Cooke, 'O’Hair, Madalyn Murray’ in Tom Flynn (ed), The New Encyclopedia of Unbelief (Foreword Richard Dawkins, Prometheus Books 2007) 581-583. 44 See on him Clarence Darrow, The Story of My Life (Charles Scribner's Sons 1932). 
Tennessee Williams dedicated a play to him: Not about Nightingales (1938). It features this sentence: 'This play is dedicated to the memory of Clarence Darrow, the Great Defender, whose mental frontiers were the four corners of the sky.' Darrow also worked in the field of criminology, writing Crime, Its Cause and Treatment (1925), and he was an activist for the abolition of the death penalty.

In the modern world, a system with a state religion is increasingly viewed as an anomaly, for the reasons mentioned.

In May of 2014, Norway decided to separate the protestant, Lutheran Church from the state. ${ }^{45}$ There was a great deal of support for this. In Parliament, there were 161 votes in favor and only 3 against.

This looked promising. Unfortunately though, the Norwegian Parliament made a number of reservations that can be viewed as conflicting with the measures being taken. One of these reservations was: 'The Norwegian Church will continue to have a special basis in the Constitution and the state will be built upon 'our Christian and humanistic heritage'. 46 This is odd and inconsistent. If the Norwegian Church is no longer a state Church, then there is no reason to mention it in the Constitution. At least, not as long as Wicca, Scientology, Hinduism, and Islam are excluded from the Constitution (which is undoubtedly the case). And references to 'our Christian and humanistic heritage' are fine, but they belong in the history books, or in treatises on cultural sociology, not in a constitution. The constitution is a legal document that encodes the legal building blocks of the state, not a textbook about a country's cultural history. ${ }^{47}$

Those who believe that these things are 'inseparable' miss the point: they should be separated.

Other developments in Norway are equally worrying. The newspaper's report that now, that the Evangelical Lutheran Church is no longer the state religion, it will receive public funding 'on par with other religious and faith-based communities.' Apparently, the Norwegian Church is still financed by the state, only now that is 'on par' with 'other religions.' So Norway is still not treating all citizens equally. It may have given up its privileged treatment of Christianity, but it has replaced it with other privileges. Now, all religions can receive preferential treatment over non-belief.

45 'Norway goes secular, removes Lutheran Church as state religion' The National Post (24 May 2014).

46 ibid.

47 See on the nature and function of constitutions KC Wheare, Modern Constitutions (Oxford University Press 1951) and James Bryce, 'Flexible and rigid constitutions' in Studies in history and jurisprudence (Volume I, Scientia Verlag Aelen 1980 [Oxford 1901]) 145-252. 
According to the fifth model (the secular or agnostic state), which we will discuss after this, this is still wrong. But first we will further analyze the fourth model of the relationship between religion and state, because that is really what Norway has now become.

\section{What is a Multiculturalist State?}

The fourth state tries to avoid the problem of unequal treatment by trying to support all religions equally. The state does not have an obligation to a single religion, but to all of them: the obligation to treat them all the same. This, apparently, is also the ambition of the Norwegian state, as we saw in the previous paragraph. This model is often inspired by a type of discourse that can be qualified as multiculturalist. ${ }^{48}$

Multiculturalism was developed by theorists like Bhikhu Parekh (b 1935) ${ }^{49}$ and Charles Taylor ( $b$ 1931), ${ }^{50}$ who wanted to give religious and ethnic communities special rights in relation to the state, for instance to resolve their own legal disputes.

Multiculturalists advocate, for instance, for special Jewish and Islamic courts to settle the disputes of members of those religious communities. ${ }^{51}$ And the state, or the national community, is expected not to interfere in intercommunal affairs.

As said, the multiculturalist state ${ }^{52}$ does not just discriminate against other worldviews, but also against non-believers (agnostics, atheists, and humanists-

48 Charles Taylor, 'The Politics of Recognition' in Charles Taylor, Multiculturalism: Examining the Politics of Recognition (Edited and introduced by Amy Gutman, Princeton University Press 1994) 25-75. See also Jocelyn Maclure and Charles Taylor, Secularism and Freedom of Conscience (Harvard University Press 2011); Jocelyn Maclure and Charles Taylor, Laïcité et liberté de conscience (La Découverte 2010) in which Taylor uses the language of secularism to defend a multiculturalist message.

49 Bhikhu Parekh, A New Politics of Identity: Political Principles for an Interdependent World (Palgrave Macmillan 2008); Bhikhu Parekh, Rethinking Multiculturalism: Cultural Diversity and Political Theory (Macmillan Press 2000). See also Machteld Zee, Choosing Sharia: multiculturalism, Islamic fundamentalism and British Sharia Councils (PhD dissertation Leiden 2015).

50 Taylor (n 48).

51 See Machteld Zee, 'Five Options for the Relationship between the State and Sharia Councils' (2014) Vol 16 Journal of Religion and Society 1-18; Zee (n 49).

52 As is clear from this passage, we make a distinction between a 'multicultural society,' in which people with different cultural and religious backgrounds live together, and 'multiculturalism' as an ideology, a political philosophy, for the state. A multiculturalist state is a state that furthers multiculturalist policy, such as the establishment and defense of group rights (instead of individual rights). 
those who do not belong to a religious denomination)..$^{53}$ Moreover, in a world filled with a plethora of religious beliefs, it is nearly impossible to distinguish religious beliefs from non-religious beliefs. What, for instance, is the nature of Scientology? Or Wicca? Should these, generally regarded as more eccentric, religious belief systems be financed by the state in the same way that the official religions are? And what to do about religions that encourage practices that we view as conflicting with human rights or the foundations of a liberal-democratic order.

With the publication of Susan Moller Okin's (1946-2004) essay Is Multiculturalism Bad for Women? (1999), ${ }^{54}$ another aspect of multiculturalism came to the fore: the frequent glossing over of bad cultural practices. Although multiculturalists do not approve of them, they also do not explicitly disapprove. Here, the mechanism we saw in Van Reybrouck is at work: passivity in criticizing bad practices because the critic, or better yet, the tradition in which he is placed ('Western'), is presumed to carry guilt of its own.

This multiculturalist nonjudgmentalism prevented all sorts of unsavory practices taking place among ethnic and religious minorities from being addressed. The most famous of these is female genital mutilation.

Again: of course it would be going much too far to claim that multiculturalists advocate such practices. Of course they do not. But the problem is: they also do not feel it is their place to judge (and reject) these things. Multiculturalism is a philosophy that turns appeasing what is wrong into a virtue.

Here, we have to stress that a clear distinction must be made between a multicultural society and a multiculturalist state.

In everyday language, the word multiculturalism is sometimes also used to simply describe pluralism. ${ }^{55}$ 'You have always cherished multiculturalism,' Giles Vanderpooten says to Stéphane Hessel (1917-2013). ${ }^{56}$ To which Hessel replies that you 'have to be open' to different cultures. ${ }^{57}$ Everyone 'has a right' to his own

53 Brian Barry, Culture \& Equality: An Egalitarian Critique of Multiculturalism (Polity 2001); AC Grayling, 'Multiculturalism' in AC Grayling, Ideas that Matter: A Personal Guide for the 21st Century (Weidenfeld \& Nicholson 2009) 246-249.

54 Susan Moller Okin, 'Feminism and Multiculturalism: Some Tensions' (Juli 1998) 108 Ethics 661-684; Susan Moller Okin, Is Multiculturalism Bad for Women? (With respondents, red Joshua Cohen, Matthew Howard and Martha Nussbaum, Princeton University Press 1999).

55 'Le multiculturalisme est quelque chose qui vous tient à cœur. De fait, il est indéniable qu'il faut s'ouvrir aux autres cultures,' Gilles Vanderpooten says to Stéphane Hessel. See Stéphane Hessel, Engagez vous!, Entretiens avec Gilles Vanderpooten (Éditions de l'aube 2013) 49. Also see on this Stanley Fish, 'Boutique Multiculturalism, or Why Liberals Are Incapable of Thinking about Hate Speech' (Winter 1997) Vol 23, No 2 Critical Inquiry 378-395.

56 Hessel (n 55) 49.

57 ibid. 
culture, Hessel says. This is a truth we have to respect. Only on this basis can we have coexistence instead of conflict, he says.

That sounds good. On the other hand, Hessel wants to stimulate a younger generation to get involved in moral projects. He says he wants to do this 'to change the world.' He encourages us to be angry, irritated, and furious.

But the problem is: 'respect for culture' is not a good point of departure for changing the world. It is a good principle for diplomats, but not for Luther, Voltaire, Martin Luther King, or other great reformers. In other words: with all due respect for Hessel, you should, in truth, not always be open to different cultures. You should really only be open to them when they constitute an improvement over your own cultural pattern. 'Being open' to cultural patterns you should be criticizing is harmful; it undermines cultural heritage that deserves to be defended. It does not stimulate vigilance against evil tendencies in this world.

Perhaps an example can clarify things here. It is an example from the Danish cartoon crisis. The creation of satire of religious figures is a tradition that deserves to survive, we believe. Making jokes about quasi-religious matters keeps religious fanaticism in check. ${ }^{58}$ As such, allowing this tradition of satire and mockery to disappear would have harmful effects.

Nevertheless, we see that satire about religion is defended less and less in the world of today. 'Righteous indignation,' especially its most violent forms, is gaining ground.

On 15 November 2006, at the height of the Danish cartoon crisis, British journalist and intellectual Christopher Hitchens (1949-2011) gave a lecture in Hart House, at the University of Toronto, Canada. Canada is a country where multiculturalism is official government policy, and unfortunately, it has frequently had serious and often negative consequences. ${ }^{59}$ One of the biggest problems seems to be that 'tolerance' too often means tolerance for the intolerant, and 'respect' means respect for the disrespectful. ${ }^{60}$ Hitchens addressed this decadence in his lecture at the height of the crisis. He criticized his audience for the sympathy that existed, not for the Danish cartoonists that had decried the radicals, but for the extremists who

58 Mick Hume, Trigger Warning: Is the Fear of being offensive killing Free Speech? (Willam Collins 2015).

59 Astute critics of Canadian multiculturalism are Neil Bissoondath, Selling Illusions: The Cult of Multiculturalism in Canada (Penguin Books 1994); Mark Steyn, America Alone: The End of the World as we know it (Regnery Publishing, Inc 2006); Mark Steyn, Lights Out: Islam, Free Speech and the Twilight of the West (Stockade Books 2009).

60 See on this HE Baber, The Multicultural Mistique: The Liberal Case against Diversity (Prometheus Books 2008); Rumy Hasan, Multiculturalism: Some Inconvenient Truths (Politico's Publishing Ltd 2010). 
were trying to suppress free speech. Hitchens said to the room: 'Shame on you, ladies and gentlemen. You are letting this happen.'

And that is the truth of it: freedom that is not defended is destined to disappear, at least if people let it happen.

Unfortunately, multiculturalism as a political philosophy is at the root of respect for disrespectful fanaticism. Still, many of Moller Okin's ${ }^{61}$ colleagues at the university found it hard to give up their multiculturalist perspectives.

Politics took to this with much greater alacrity than academia. In 2010, German Chancellor Angela Merkel proclaimed the death of multiculturalism. ${ }^{62}$ The same message could be heard from French President Nicolas Sarkozy. ${ }^{63}$ Another voice in the anti-multiculturalism choir was that of British Prime Minister David Cameron, who said that state multiculturalism had failed. ${ }^{64}$ This makes it sound like multiculturalism is a lost cause, but, as we will see, although Cameron and Sarkozy agreed about what they chose to reject, they differed greatly on what they were willing to accept.

Based on these considerations, we can conclude that it seems the better course to give up all state aid to religion and adopt a religiously neutral posture in everything involving the state. This is the fifth model of the relationship between state and religion, which we will examine now.

\section{What is an Agnostic or Secular State?}

This last state can be called the secular state or the agnostic state. It is the fifth model of the possible relationships between state and religion. Before we examine this model more closely, we must make a note on semantics.

An agnostic is someone who does not adopt a position on the question if God exists. He suspends his judgment about this. ${ }^{65}$ Whether agnosticism is a viable position from the perspective of the individual is not relevant in the context of this

61 Another early critic of multiculturalism along these lines is Jeremy Waldron, 'Minority Cultures and the Cosmopolitan Alternative' (1992) Vol 25 University of Michigan Journal of Law Reform 751793.

62 'Merkel erklärt Multikulti für gescheitert' Spiegelonline (16 October 2010).

63 'Nicolas Sarkozy declares multiculturalism had failed' The Telegraph (11 February 2011).

64 'State multiculturalism has failed, says David Cameron' BBC News (5 February 2011).

65 Paul Cliteur, 'Atheism, Agnosticism, and Theism' in Paul Cliteur, The Secular Outlook: in Defense of Moral and Political Secularism (Wiley-Blackwell 2010) 14-69; John Bernard Dalgairns, 'Is God unknowable?' in Contemporary Review (Vol XX, 1872) 615-630, also in Andrew Pyle (ed), Agnosticism: Contemporary Responses to Spencer and Huxley (Thoemmes Press 1995) 20-38; Thomas Henry Huxley, 'Agnosticism and Christianity', 1889, in Thomas Henry Huxley, Agnosticism and Christianity. And other Essays, (Prometheus Books 1992) 193-232. 
chapter, but we will defend here that it is a legitimate and even beneficial position for a state. A great advantage of the agnostic state is that it does not make a distinction between its citizens. The agnostic state treats all citizens equally. The agnostic or secular state does not combat the religious convictions of its citizens, but it does not defend any religious position either. The agnostic state allows all citizens worship the gods of their choice.

As such, agnosticism (or secularism) with regard to religion seems a wise path to take when it comes to government policy. A state that has adopted political agnosticism or secularism as its official governing principle is France.

The French minister of immigration and integration described this open character of the French state in a lecture in 2010, when he said that France is not a people, or a language, or a territory, or a religion, but a conglomerate of people who want to live together ('vivre ensemble'). ${ }^{66}$ To make this 'living together' possible, it is important that the state does not identify itself with what divides people: their religion. But although the French state has always championed this policy of secularism, even devising a special word for it (laïcité), it is not an exclusively French principle. The great historian of Islam and Islamic societies, Bernard Lewis ( $b$ 1916) pointed to a nearly forgotten American declaration of the same ideal. He quoted the 'somewhat neglected John Tyler,' who, in a letter of 10 July 1843 , gave eloquent voice to the principle of freedom of religion:

The United States have adventured upon a great and noble experiment, which is believed to have been hazarded in the absence of all previous precedent-that of total separation of Church and State. No religious establishment by law exists among us. The conscience is left free from all restraint and each is permitted to worship his Maker after his own judgment. The offices of the Government are open alike to all. No tithes are levied to support an established Hierarchy, nor is the fallible judgment of man set up as the sure and infallible creed of faith. The Mahommedan, if he will to come among us would have the privilege guaranteed to him by the constitution to worship according to the Koran; and the East Indian might erect a shrine to Brahma if it so pleased him. Such is the spirit of toleration inculcated by our political Institutions [...]. The Hebrew persecuted and downtrodden in other regions takes up his abode among us with none to make him afraid [...] and the Aegis of the Government is over him to defend and protect him. Such is the great experiment which we have tried, and such are the happy fruits which have resulted from it; our system of free government would be imperfect without it. The body may be oppressed and manacled and yet survive; but if the mind of man be fettered, its energies and faculties perish, and what remains is of the Earth, earthly. Mind should be free as the light or as the air. ${ }^{67}$

66 Éric Besson, in a speech of 5 January 2010: 'La France n'est ni un peuple, ni une langue, ni un territoire, ni une religion, c'est un conglomérat de peuples qui veulent vivre ensemble.' Cited in Alain Finkelkraut, L'identité malheureuse (Éditions Stock 2013) 105.

67 Bernard Lewis, 'The Roots of Muslim Rage' in The Atlantic Monthly, September 1990, reprinted in Bernard Lewis, From Babel to Dragomans: Interpreting the Middle East (Weidenfeld \& Nicolson 2004) 319-331. 
So much for the American President John Tyler (1790-1862).

\section{Is Secularism Typically Western?}

There is one view that stands in the way of the further spread of secularism, and that is that it is claimed to be a typically Western concept. We disagree. Here, we can refer to Bishop Nazir-Ali, with whom we began this chapter, but this time for a view with which we fully agree.

Bishop Nazir-Ali points to the political philosophy of Pakistan at the time of the state's founding. Religious tensions were resolved peacefully. Women were free to go where they pleased and wear what they wanted. ${ }^{68}$ Karachi was a cosmopolitan city that drew a great diversity of visitors, and non-Muslims were a prominent feature of everyday life. As Nazir-Ali writes, all of this was in accordance with what the founder of the Pakistani state, Mohammad Ali Jinnah (1876-1948), had intended: 'Religion had little to do with the workings of the state. ${ }^{69}$ Jinnah was, in other words, a secularist.

And secularism is not a kind of colonial vestige of Western thought; in nonWestern traditions, too, there are countless countries where a secular vision of the state has taken root. $^{70}$

This is especially important in a time and context when states are being challenged to legitimize their own existence. Modern theoterrorism is, in a way, forcing states to formulate answers to the criticism they face. Ignoring the criticism and pretending it does not exist does not seem to be a wise course. So let us end this chapter with the observation that both a religiously neutral political language and a religiously neutral state are the best answers to modern-day theoterrorism and religious extremism. The revival of theocracy is best countered by relinquishing all remnants of religious discrimination in our liberal democratic states.

68 Nazir-Ali, Triple Jeopardy for the West: Aggressive Secularism, Radical Islamism and Multiculturalism (Bloomsbury 2012) 95.

69 ibid. We quote this passage because it is so astonishing that the same author is also highly negative about modern-day prognoses of secularism. In the subtitle of his book, Nazir-Ali turns against what he calls 'aggressive secularism.' He does not make clear what he means by this though. See also Alain Finkelkraut, L'identité malheureuse (Éditions Stock 2013) 18.

70 See for the Indian tradition: Finngeir Hiorth, Introduction to Atheism (Indian Secular Society 1995); Finngeir Hiorth, Introduction to Humanism (Indian Secular Society 1996); Amartya Sen, 'Secularism and Its Discontents' in Amartya Sen (ed), The Argumentative Indian: Writings on Indian History, Culture and Identity (Allen Lane/Penguin Books 2005) 294-316; Amartya Sen, Identity and Violence: The Illusion of Destiny (WW Norton \& Company 2006). 


\section{The French Laïcité as Consistent Secularism}

But there is a condition. The agnostic or secular state is based on the assumption that the state itself is religiously neutral. This means that civil servants are expected not to express their personal religious convictions. ${ }^{71}$ In France, this model is realized by means of the principle of so-called laïcité.

As a result of the conclusions drawn by a state commission on the matter, the Stasi commission, the French state created legislation governing the wearing of religious symbols in French public schools and by people employed by the government. ${ }^{72}$ Especially the ban on religious symbols in schools (not just crucifixes and yarmulkes but also Islamic headscarves) led to a long and sometimes bitter controversy between opponents and proponents of the neutrality principle. ${ }^{73}$ One of the most frequent complaints about the French system is that it targets Muslim women. It is their religious right to wear headscarves. When the system denies them this right, the system is inherently discriminatory.

The cultural historian Andrew Hussey ( $b$ 1963) writes about the riots in the French banlieus and how France reacted to them in his book The French Intifada (2014). Most commentators agreed that this was a social justice issue, not a cultural one. Hussey does not believe this is true. He posits that there is a 'very real conflict in modern-day France between the opposing principles of laïcité and communitarianism, which is expressed in the riots. ${ }^{, 74}$

Hussey is right, we believe, when he says that these riots reveal an issue of principle (although one cannot agree with his insinuation that, therefore, the French system is illegitimate).

The French ban on full face covering in public drew a great deal of criticism. At the front lines of this debate was the then French president, Nicolas Sarkozy, who

71 See on the French system: Murat Akan, 'Laïcité and multiculturalism: the Stasi Report in context' (2009) 60 (2) The British Journal of Sociology 237-256; Patrick Weil, 'Why the French Laïcité is Liberal' (2009) 30 (6) Cardozo Law Review 2699-2714.

72 Laïcité et République, Rapport au Président de la République, Commission présidée par Bernard Stasi, La Documentation française 2004; Robert O’Brien, The Stasi Report: The Report of the Committee of Reflection on the Application of the Principle of Secularity in the Republic (William S Hein \& Co, Inc 2005).

73 One of the earliest manifestations was: Elisabeth Badinter, Regis Debray, Alain Finkelkraut, Elisabeth de Fontenay, Catharine Kintzler, 'Profs, ne capitulons pas!' Le Nouvel Observateur (2/8 November 1989). Een latere selectie van standpunten in Jean-Michel Helvig, La laïcité dévoilée. Quinze années de débat and quarante « Rebonds », Líberation/éditions de l'aube, Paris 2004. 74 Andrew Hussey, The French Intifada: the Long War between France and its Arabs (Faber \& Faber 2014) 8. 
declared in June of 2009 that the burka ${ }^{75}$ was not welcome in France. ${ }^{76}$ In his first presidential address to a joint session of both chambers of the French Parliament (the first in 136 years), he declared his support for a ban. He said: 'We cannot accept that, in our country, women live behind nets, cut off from social life, robbed of their identities. ${ }^{77}$ The president also referred to human dignity, applied to women: 'This is not the idea the French Republic has of the dignity of women. ${ }^{78}$ And the most relevant quotation in the context of this chapter: 'The burka is not a religious symbol, but a symbol of submissiveness, and it will not be welcome on the territory of the French Republic.' In France, there is a broad consensus between left and right about the burka. André Gerin (b 1946), a member of the communist party who led the latest investigation into this religious-cultural phenomenon called the burka a 'mobile prison' for women. ${ }^{79}$

But there is also a great deal of criticism of the French system, especially from Anglo-Saxon countries that are more oriented toward multiculturalism. This criticism comes in two forms. ${ }^{80}$ First, it is often said that the French authorities intended to target the Muslim community. And how could it be otherwise? The Christians do not wear religious symbols to school (or in a much more limited way; a cross around the neck is not very noticeable and, moreover, it is easy to wear it even less visibly). Second, it is argued that, although the French state does not intend to discriminate against those who wear headscarves, this is the effect.

Let us briefly comment on both objections. First, the argument of discriminatory intent.

On 15 March 2004, a French law was announced that stipulated that 'in primary and secondary schools, the wearing of symbols or clothing that clearly express a religious faith is prohibited.' Cécile Laborde, a commentator with a French background, but clearly no friend to the French system, offers the following

75 The burka is a garment that covers the face, in contrast with the headscarf, which only covers the hair.

76 Peter Allen, 'Nicolas Sarkozy says the burqa is 'not welcome' in France' The Telegraph (22 June 2009).

77 ibid.

78 ibid.

79 ibid.

80 Although the French system is rejected almost everywhere in the Anglo-Saxon world, it has some knowledgeable defenders in the French-speaking world, such as: Jeanette Bougrab, $M a$ république se meurt, (Éditions Grasset \& Faquelle 2013); Caroline Fourest, Quand la gauche a du courage: chroniques résolument progressistes et républicaines (Grasset 2012); Henri Pena-Ruiz, Dictionnaire amoureux de la laïcité (Plon 2014); Alain Finkelkraut, L'identité malheureuse (Éditions Stock 2013); Régis Debray, Ce que nous voile le voile: La République et le sacré (Gallimard 2004); Catherine Kintzler, Qu'est-ce que la laïcité? (La librairie philosophique J Vrin 2007). 
commentary on this law: 'This law is aimed at Islamic headscarves, although Jewish yarmulkes and Christian crosses are also banned in public schools. ${ }^{81}$

The question is whether this is an overly tendentious description of the situation. What does the quoted sentence mean? Is it possible to say, as this writer does, that this law is primarily 'aimed at' Islamic headscarves, if she has to mention in the same breath that it applies to all religious symbols? From what does she conclude that is it aimed at the Islamic headscarf in particular? Would it not be better to say that this law was aimed at the wearing of religious symbols in general, and thus also against headscarves? That has a very different ring to it, does it not?

Laborde's phrasing seems to suggest that the French legislator has the explicit intention of targeting the Muslim community. What are her arguments for this serious accusation?

Why does Laborde not say: 'The law is aimed at headscarves, yarmulkes, large crosses [...], et cetera'? If it had been phrased like that, the sentence would have been unnecessary, of course, but also much less tendentious.

Commentators on the French state often feel that they have observed something of great importance when say that the French law banning the wearing of religious symbols was drafted in response to the wearing of headscarves. But in reality that is nothing more than a historical fact of very limited relevance to the principle. Perhaps this can be illustrated by an example.

The kirpan is a ceremonial sword or knife worn by Sikhs. In the Sikh community, the wearing of this dagger is viewed as a religious precept. This precept goes back to a command by the guru Gobind Singh (1666-1708) who decided in 1699 that all Sikh's must wear this 'religious dagger.'

Now imagine that there were not many Muslims living in France, but a great many Sikhs instead. And say the French government had tightened legislation banning the wearing of religious symbols in public schools. Would it then be possible to say that the French state had the intention of targeting the Sikhs in particular?

We think it would be misleading to make that claim. By phrasing it like that, the misconception that the French state has it out for Sikhs in particular is introduced, when that state is doing nothing more than enforcing a constitutional principle, also with regard to Sikhs.

If the state did not do that last, if it granted a special privilege to a particular religious community, giving it an exemption from the general law, the state would be making a grave mistake. And that is discriminating against religious groups that are willing to comply with the law.

81 Cécile Laborde, 'Secular Philosophy and Muslim Headscarves in Schools' (2005) 13 (3) The Journal of Political Philosophy 305-329, 325. 
The second form of criticism that is often leveled against the French system is that, regardless of the French authorities' motives, the system has the indirect effect of primarily impacting the Muslim community. So it is not about the French government's intention but about the unintended effect of the legislation. For Christians, wearing headscarves is not a religious duty, so they are not impacted by a prohibition against it; Muslims are. So should we not say that indirectly Muslims are affected more by the prohibition against wearing evidently religious symbols?

A few things can be said in response to these arguments. The first critique (the 'bad intentions' theory) assumes a kind of conspiracy. It tries accuse those who support a rational political philosophy (and whatever one may say about laïcité; it is a clear and consistent position) ${ }^{82}$ of darker 'true motives' that the people in question, or the state that is taking the action, are keeping under wraps. ${ }^{83}$ The second version of this argument, the argument of indirect discrimination, has more merit, but does not convince in the end either. ${ }^{84}$ The problem with the argument of indirect discrimination is that it fails to recognize that, when you make a rule that prohibits a certain behavior, there will always be a group (with certain specific characteristics) whose behavior is particularly affected by that rule.

Take the rule that forbids sex with children below a certain age. This rule affects pedophiles. That is hard to deny. But does it make sense to say that the rule 'discriminates against people for their sexual orientation' (pedophilia)?

This brings us to the complex question of when a particular rule is 'discriminatory.' It does not seem unreasonable to us to defend that a rule is 'discriminatory' when a type of behavior that is prohibited for one group is allowed for another.

So say that Muslims were not allowed to wear headscarves, but Jews were allowed to wear yarmulkes. In such a situation, complaints about discrimination would be justified (and necessary). But in the case of the ban on the wearing of religious symbols (regardless of whether they are Christian, Jewish, or Islamic in nature), there is no discrimination, even if a particular group is more affected by the ban.

82 For a recent defense, see Henri Pena-Ruiz, Dictionnaire amoureux de la laïcité (Plon 2014). Other proponents of the system are: Fourest (n 80); Debray (n 80); Alain Finkelkraut, L'identité malheureuse (Éditions Stock 2013).

83 This is defended with great vigor in: Joan Wallach Scott, The Politics of the Veil (Princeton University Press 2007), but also, unfortunately, in: Martha Nussbaum (ed), The New Religious Intolerance: Overcoming the Politics of Fear in an Anxious Age (Harvard University Press 2012).

84 We also encounter this in Laborde: 'Laïcité was intended as a principle of equality, yet it can be argued that the ban on headscarves constitutes a case of indirect discrimination and thus infringes on equality. See Laborde (n 81) 329. 
This point is not only made in the context of the wearing of religious symbols, but also, for instance, in the discussion about the death penalty. ${ }^{85}$ It is a statistical fact that more black people end up on the electric chair than white people. Does this mean that the death penalty is 'discriminatory'? Although there are many convincing arguments against the death penalty, this is not one of them. What the death penalty 'discriminates against' is murder (or other crimes for which it is imposed), but it does not discriminate against black people. It would be discriminatory if a white man were to be acquitted for an act or behavior for which a black man would have been convicted.

It is, however increasingly difficult to uphold secular principles in an age where religious fanaticism is so influential. We finish this chapter by presenting some recent case law of the European Court of Human Rights in defending freedom of speech against attempts to stifle that principle.

\section{Abdullah Riza Ergüven (2005)}

Freedom of speech and freedom of religion are severely jeopardized by 'theoterrorist assault' on these principles. Jihadists have vowed to destroy these principles, and governments of secular nation-states have great difficulty in countering their attempts. Can the judiciary be of any help?

When it comes to its case law on the freedom of expression, the European Court has developed two opposite positions. One position protects the right to 'offend shock and disturb. ${ }^{86}$ The other position protects hurt feelings of religious believers against the freedom of expression. ${ }^{87}$

Most of the Court's case law was developed against a Christian backdrop. Should, for instance, Catholic symbols get special protection by the law (and from the Court)? Since 2001, however, discussion about other religions and their adherents' feelings has also reached the European Court. In 2005, the same year the Danish cartoons set Europe on fire (literally, as Danish embassies were burned because of the pictures), ${ }^{88}$ there was a case before the Court on freedom of expression in Turkey. $\dot{I} A$ v Turkey (2005) was about a publishing house that had released a novel by

85 See, eg, Louis Pojman, 'In Defense of the Death Penalty' in Hugh LaFolette (ed), Ethics in Practice. An Anthology (Blackwell 2002) 493-502; Ernest van den Haag, 'The Death Penalty Once More' (Summer 1985) 18 UC Davis Law Review 957-972.

86 Handyside $v$ UK (1976) Series A No 24; (1979-80) 1 EHRR 737.

87 Otto Preminger Institute v Germany (1994) Series A no 295-A; (1995) 19 EHRR 34.

88 Jytte Klausen, The Cartoons that Shook the World (Yale University Press 2009); Flemming Rose, The Tyranny of Silence: How One Cartoon Ignited a Global Debate on the Future of Free Speech (Cato Institute 2014). 
Abdullah Riza Ergüven titled Yasak Tümceler ('The forbidden phrases'). ${ }^{89}$ Although the book is a novel, it also deals with philosophical and theological issues. ${ }^{90}$ The publisher was convicted under Article 175 of the Turkish Criminal Code, which penalizes blasphemy against 'God, the Religion, the Prophet and the Holy Book.' 91 An expert report by Professor Salih Tuğ, dean of theology at Marmara University, was especially critical of Ergüven's novel. As Tuğ declared, Ergüven 'imprisons readers within the limits of his own views, which are devoid of all academic rigors. [...] He criticizes the beliefs, ideas, traditions, and way of life of Anatolian Turkish society by adopting the independent and nonconformist viewpoint of the leaders, thinkers and scientists of the Renaissance to enlighten and advise our people as he sees fit. "92 'This way of thinking,' Professor Tuğ continues, is ‘based on materialism and positivism, leads to atheism in that it renounces faith and divine revelation.,93

These matters were of grave concern to the expert, but worse was that it may be observed that they also contain statements that imply a certain element of humiliation, scorn and discredit vis-⿳亠丷⿵冂-vis religion, the Prophet and belief in God according to Islam. ${ }^{94}$ Professor Tuğ summarizes the novelist's views:

In the author's view, religious beliefs and opinions are mere obscurities, and ideas based on nature and reasons are described as clear-sighted. The author describes religious faith as a 'desert mirage', a 'primitive idea' and 'desert ecstasy', and religious practices as 'the primitivism of desert life.'95

One may object that this is nothing special from the perspective of the French (Voltaire), British (Locke, Hume), and American (Jefferson, ${ }^{96}$ Paine $^{97}$ ) Enlightenment philosophers. ${ }^{98}$ So, the question is whether these forms of expression should not be protected under a human rights regime.

This is certainly not the view of the Turkish authorities, and in this case they were not contradicted by the European Court in Strasbourg. Why not? The Court answered,

89 İ A v Turkey App no 42571/98 (ECtHR, 13 September 2005).

90 ibid para 5.

91 ibid para 6.

92 ibid para 7.

93 ibid.

94 ibid.

95 ibid.

96 Thomas Jefferson, 'I too am an Epicurean' Letter to William Short in Thomas Jefferson, Writings (31 October 1819, The Library of America 1984) 1430-33.

97 See, eg, Thomas Paine, 'The Age of Reason' in Thomas Paine, Collected Writings (first published 1794, The Library of America 1995) 665-885.

98 Margaret C Jacob, The Secular Enlightenment (Princeton University Press 2019); Matthew Stewart, Nature's God: The Heretical Origins of the American Republic (WW Norton \& Company 2014). 
referring to the Handyside case, that although pluralism, tolerance, and broadmindedness are the 'hallmarks of a democratic society, ${ }^{, 99}$ there is a limit. 'The present case,' the Court said, 'concerns not only comments that offend or shock, or a 'provocative' opinion, but also an abusive attack on the Prophet of Islam.' It continued,

\begin{abstract}
Notwithstanding the fact that there is a certain tolerance of criticism of religious doctrine within Turkish society, which is deeply attached to the principle of secularity, believers may legitimately feel themselves to be the object of unwarranted and offensive attacks through the following passages: 'Some of these words were, moreover, inspired in a surge of exultation, in Aisha's arms. [...] God's messenger broke his fast through sexual intercourse, after dinner and before prayer. Muhammad did not forbid sexual intercourse with a dead person or a live animal. 100
\end{abstract}

Apparently, the clauses of the Handyside case that one may hold opinions that 'offend shock or disturb' as protected by the freedom of expression are not applicable when it comes to an 'abusive attack on the Prophet of Islam.'101

The Court ruled that there was no violation of Article 10 of the Convention (i. e., the right to freedom of speech). But this judgment was supported by only a small majority (four votes to three) of the judges. The three dissenting voices protested that 'a democratic society is not a theocratic society' ${ }^{102}$ :

Freedom of the press relates to matters of principle, and any criminal conviction has what is known as a 'chilling effect' liable to discourage publishers from producing books that are not strictly conformist or 'politically (or religiously) correct.' Such a risk of self-censorship is very dangerous for this freedom, which is essential in a democracy, to say nothing of the implicit encouragement of blacklisting or 'fatwas.' 103

Only one year later, in 2006, the Court heard another case on free speech involving Turkey. This time it was not about a novelist but a journalist. This time, the result was the complete opposite.

\title{
10 Erdoğan Aydın Tatlav (2006)
}

Mr Erdoğan Aydın Tatlav published five volumes titled İslamiyet Gerçeği ('The Reality of Islam'). ${ }^{104}$ The first of these volumes, published in 1992, criticized the

99 İ $A$ v Turkey App no 42571/98 (ECtHR, 13 September 2005) para 28.

100 ibid para 29.

101 ibid.

102 ibid para 5, dissenting opinion.

103 ibid para 6, dissenting opinion.

104 This case is only available in French: Aydin Tatlav $v$ Turkey App no 50692/99 (ECtHR, 2 May 2006). 
Koran. ${ }^{105}$ Philosopher Russell Blackford characterizes Tatlav's work as a 'blatantly atheistic and anti-religious book,' but the expert did not mean that abuse but as praise. ${ }^{106}$ In his work, Tatlav analyzed the development of religious thinking, the logic of the Koran with regard to proof of God's existence, the notions of paradise and hell in the Koran, whether the Koran is subject to change and interpretation, the way the Prophet Mohammed received his revelations, and the question whether the religion of Islam is a tribal creed. In 4 years, 16,500 copies were sold. ${ }^{107}$ But although there was no reaction from Turkish authorities, in 1997 the Turkish public prosecutor in Ankara accused the author of having published a book 'profaning one of the religions.' ${ }^{108}$ This religion was, of course, Islam. One of the complaints of Tatlav's treatment of the matter was that he had scolded Islam for the extreme sensitivity of the Islamic believers. Apparently, Islam was a religion that lacked self-confidence, Tatlav claimed. This lack of self-confidence also manifested itself in the extreme cruelty of the sanctions prescribed by the Koran. ${ }^{109}$ Tatlav was also quite explicit about the Prophet Mohammed. Mohammed, Tatlav wrote, took his dreams for reality, he presented verses that were absolutely crazy, ${ }^{110}$ and he promised an afterlife for men living the lives of parasitic aristocrats. Before the judicial authorities Tatlav made clear that he wanted to have his books considered scientific treatises on all religions and prophets. ${ }^{111}$ It cannot come as a surprise that Tatlav also maintained that God cannot exist. ${ }^{112}$

Like in IA $v$ Turkey, Tatlav was prosecuted under Article 175 of the Turkish penal code. But this time the judgment was totally different. The European Court recapitulated precedents on freedom of speech and considered the grounds justifying Otto Preminger's condemnation. But this time the Court said that it could not find an insulting tone toward other believers or an attack on sacred symbols ('un ton insultant visant directement la personne des croyants, ni une attaque injurieuse pour des symboles sacrés [...]'). ${ }^{113}$ The Court came to a unanimous support of freedom of speech.

105 ibid para 9.

106 Russell Blackford, Freedom of Religion \& the Secular State (Wiley-Blackwell 2012) 184. For Blackford's own views, see Russell Blackford and Udo Schüklenk, 50 Great Myths about Atheism (Wiley-Blackwell 2013); Russell Blackford, The Tyranny of Opinion: Conformity and the Future of Liberalism (Bloomsbury 2018).

107 Aydin Tatlav v Turkey App no 50692/99 (ECtHR, 2 May 2006) para 10.

108 ibid para 12.

109 ibid.

110 ibid.

111 ibid para 13.

112 ibid para 14.

113 ibid para 28. 
It is not easy to find some consistency in the European Court's judgments on blasphemy bans. ${ }^{114}$ This holds true particularly for the last judgment we want to discuss, a case that arose in Austria. This time the defendant was not a novelist (IA) or a research journalist (Tatlav) but a social activist.

\section{Elisabeth Sabaditsch-Wolff (2018)}

Elisabeth Sabaditsch-Wolff was convicted for (i) 'denigration of religious beliefs of a legally recognized religion,' which is sanctioned in Section 188 of the Austrian Criminal Code, and (ii) incitement to hatred, penalized in Article 283 of the same code. The first article penalizes the Herabwürdigung religiöser Lehren, the defamation of religious doctrines. ${ }^{115}$ Ms Sabaditsch's conviction was based on what said during a seminar, 'Basic Information on Islam' ('Grundlagen des Islams').

On 15 October and 12 November 2009, she hosted a seminar with around 30 participants at each gathering. ${ }^{116}$ But not only were ordinary participants present. 'One of the participants was an undercover journalist working for a weekly journal.' 117

When Sabaditsch-Wolff was questioned by the police concerning 'certain statements' she had made during the seminars, it appeared that the journalist had requested preliminary investigation of her. ${ }^{118}$ The Austrian court found she was guilty of 'publicly disparaging an object of veneration of a domestic Church or religious society, namely Muhammad, the Prophet of Islam, in a manner capable of arousing justified indignation' ('geeignet, berechtigtes Ärgernis zu erregen'). ${ }^{119}$

What had Sabaditsch-Wolff said about Mohammed that led to her conviction? She was convicted based on two criticisms, one general and one specific. The more general criticism contested the status of Mohammed as 'the ideal man,' 'the perfect human. ${ }^{120}$ She voiced three complaints: first, that Mohammed was a warlord;

114 See also Jeroen Temperman, Religious Hatred and International Law: The Prohibition of Incitement to Violence or Discrimination (Cambridge University Press 2016) 361 (speaks of the 'questionable jurisprudence' of the Strasbourg Court when it comes to blasphemy bans).

115 ES v Austria App no 38450/12 (ECtHR, 25 October 2018) para 3.

116 ibid para 8.

117 ibid; see also ibid para 51: 'The applicant's statements were in fact recorded by a journalist, who had participated in the seminar, and whose employer subsequently reported them to the public prosecutor.'

118 ibid para 8.

119 ibid para 12.

120 ibid para 13. 
second, that Mohammed endorsed polygamy; and third, that 'he liked to do it with children.' For these reasons he was not the most perfect man.

One may object, what does that matter? Why is this important to digress upon in our time, more than seven centuries beyond Mohammed's lifetime? SabaditschWolff's answer to that question is that moral commentary on the life of the Prophet is important because contemporary Muslims see him as a model to emulate. So when today's Muslims get into conflicts with democracy and 'our system of values,' Sabaditsch-Wolff said, we can understand these conflicts by examining the background of the moral icon they try to copy. ${ }^{121}$

The second point that got Sabaditsch-Wolff into trouble was her more specific critique of the Prophet. For this she had used one of the most important Hadith collections available, that of Muhammad al-Bukhari (810-70). This collection of hadiths has great authority in the Muslim world. If something is included in AlBukhari's collection, it has the status of Holy Scripture. In this collection there is a story about Mohammed, being a man of middle age, and his wife Aisha. When Mohammed married Aisha, she was 6 years old, ${ }^{122}$ and the marriage was consummated when she was nine. ${ }^{123}$

According to Sabaditsch-Wolff, this was a matter of great moral concern and had far-reaching consequences. During the seminar she had discussed this by relating a conversation she had conducted with her sister on this delicate issue. The conversation revolved around how to interpret this historical issue. During that conversation she had asked her sister, 'A fifty-six-year-old and a six-year-old? What do you call that? Give me an example? What do we call it, if it is not pedophilia?, ${ }^{124}$ Her sister said, 'Those were different times.' But Sabaditsch-Wolff was adamant: 'It wasn't okay back then, and it is not okay today. ${ }^{125}$

Sabaditsch-Wolff also discussed the relevance of this story for our contemporary world: 'It is still happening today. ${ }^{126}$ She means, there are still child marriages organized in the Islamic world. The moral legitimacy of these marriages is found in a record considered historically uncontestable by at least some Muslims.

The Austrian Regional Court did not comment on whether the story was considered historically accurate in the Muslim world, nor did it discuss the significance of this story for the position of underaged girls in the Islamic word. The
121 ibid.
122 ibid.
123 ibid para 14.
124 ibid para 13.
125 ibid.
126 ibid. 
Court only commented on one aspect: Could Sabaditsch-Wolff's conversation with her sister was interpreted as conveying the message that Mohammed had 'paedophilic tendencies'? And if so, could this be considered 'publicly disparaging an object of veneration of a domestic Church or religious society'? ${ }^{127}$ The Court answered affirmatively because Sabaditsch-Wolff 'had suggested that Muhammed was not a worthy subject of worship. ${ }^{, 128}$ The word 'paedophilia' was capable of 'arousing indignation,' the Austrian Court said. A reason the Austrian Court considered the word 'paedophilia' inapplicable was that when Aisha had turned 18, the Prophet had not annulled the marriage. ${ }^{129}$

Another point discussed before the Austrian Court was whether something said at a gathering of 30 people is sufficiently 'public' to warrant a conviction. The Austrian Court answered in the affirmative because 'it was conceivable that at least some of the participants might have been disturbed by the statements. ${ }^{, 130}$

But what about the point of Mohammed's exemplary role, the Prophet being an object of emulation? The Austrian Court ignored the issue and only said that Sabaditsch-Wolff's discussion did 'not contribute to a debate of public interest.'131 Her statements had not been 'statements of fact' but only 'derogatory value statements. ${ }^{132}$ Discussing child marriages would have been possible, according to the Austrian Court, but this is not the same as pedophilia. ${ }^{133}$ Besides, child marriage is not only a 'phenomenon of Islam' but also among the European dynasties. ${ }^{134}$ The Austrian Court also scolded the applicant for her conception of (or rather lack of) tolerance. 'Presenting objects of religious worship in a provocative way capable of hurting the feelings of the followers of that religion could be conceived as a malicious violation of the spirit of tolerance, which was one of the bases of a democratic society. ${ }^{135}$ In doing what she had done, Ms Sabaditsch-Wolff had violated the 'religious peace in Austria., ${ }^{136}$

This concept of 'religious peace' is a recurrent theme in the comments of the Regional Austrian Court, as it was also in the Vienna Court of Appeal, which confirmed the applicant's conviction. The Vienna Court added another argument

127 ibid para 12.

128 ibid.

129 ibid.

130 ibid para 14.

131 ibid.

132 ibid para 15.

133 ibid.

134 ibid.

135 ibid.

136 ibid. 
to dismiss the pedophilia accusation of Sabaditsch-Wolff: Mohammed's first wife had been 15 years older than he was.

The Austrian courts convicted the accused under two articles in the Austrian Penal Code. First, Article 188, which criminalizes offenses against religious peace (Strafbare Handlungen gegen den religiösen Frieden). It reads as follows:

Whoever, in circumstances where his or her behavior is likely to arouse justified indignation, publicly disparages or insults a person who, or an object which, is an object of veneration of a Church or religious community established within the country, or a dogma, a lawful custom or a lawful institution of such a Church or religious community, shall be liable to up to 6 months' imprisonment or a day-fine for a period of up to 360 days. ${ }^{137}$

The second article is Section 283 of the Austrian Penal Code, which penalizes incitement to hatred:

1. Whoever, in a manner capable of endangering public order, publicly incites to commit a hostile act against a Church or religious community established within the country or against a group defined by its belonging to such a Church or religious community, a race, a nation, a tribe or a state, shall be liable to up to 2 years' imprisonment.

2. Similarly, whoever publicly incites against a group defined in paragraph 1 or tries to insult or disparage them in a manner violating human dignity shall equally be held liable. ${ }^{138}$

The European Court did not reject the verdicts of the Austrian courts. The Court agreed that Sabaditsch-Wolff 'must have been aware that her statements were partly based on untrue facts and apt to arouse (justified) indignation in others. ${ }^{139}$ Apparently, the Court focused on the 'untrue fact' of pedophilia while remaining silent on the age difference between Aisha and the middle-aged Prophet. There is also no further analysis in the judgment of the European Court about the right definition of pedophilia. Is it right to assume, as both the Austrian courts and the European Court do, that someone is not a pedophile if he or she also has sexual relationships with adults? Or is not a pedophile if he or she had a relationship with an adult later in life? Or that a pedophile label no longer applies once an underaged girl reaches the age of maturity?

The essence of Sabaditsch-Wolff's complaints seems to be the age difference between the religious icon and the underaged girl and the social consequences of that fact. This age difference is not an 'untrue fact,' or at least it is not contested in Islamic lore.

A somewhat uncomfortable conclusion that may be drawn from the European Court's stance in this matter is that at a time when certain elements of Islamic

137 ibid para 24.

138 ibid.

139 ibid para 54. 
culture are criticized, this criticism is stifled not only by theoterrorist attacks (Danish cartoons, French cartoons, and American cartoons) but also by judgments from the very same institutions invented to protect the freedom to criticize in 47 European countries. Just like in IA $v$ Turkey (2005), the European Court came to a unanimous judgment rejecting the applicant's recourse to freedom of expression under the European Convention of Human Rights.

The problem with ES $v$ Austria seems to be that the principles of the secular state are seriously jeopardized by the threat of religious terrorism. And in this judgment the European Court is not on the side of those who want to rescue secularism from the assault of those who pose the most serious challenge.

The authors argue that contemporary problems around religiously motivated terrorism have made the typology mentioned more topical than several decades ago. The agnostic state and its concomitant secularism (model v) is under threat by the protagonists of theocracy. Unfortunately, theocracy gets violent support nowadays from the side of religious terrorism. This means that it is all the more important and at the same time difficult to uphold the principles of a secular state. 